\title{
Deregulation of RNAi silencing pathway by Human T-cell leukemia virus type 1 bZIP factor (HBZ)
}

\author{
Hélène Gazon ${ }^{1,2,3}$, Jean-Michel Mesnard ${ }^{1,2}$, Raymond Césaire ${ }^{3}$, Jean-Marie Peloponese $\mathrm{Jr}^{1,2^{*}}$ \\ From 16th International Conference on Human Retroviruses: HTLV and Related Viruses \\ Montreal, Canada. 26-30 June 2013
}

Human T-cell leukemia virus type-1 (HTLV-1) is the causative agent of a non-Hodgkin leukemia known as adult $\mathrm{T}$ cell leukemia (ATL). MicroRNAs (miRNAs) are a class of non-coding RNAs that regulate the expression of target genes at posttranscriptional level. Biogenesis of miRNAs is tightly regulated and starts with the production of pri-miRNAs by RNA polymerase II. The pri-miRNAs are then cleaved by Drosha in conjunction with DGCR8 in the nucleus, generating pre-miRNAs, which are then transferred to the cytoplasm where Dicer1 further processes the hairpin into the mature miRNAs. With exception of few types of neoplasm, a general downregulation of miRNAs expression has been observed in cancers cells, mainly due to chromosomal abnormalities, epigenetic changes or aberrant expression of the miRNA biogenesis factors. Involvement of miRNAs alteration in the HTLV-1 life cycle has recently come to light. However, the mechanisms that regulate the expression of miRNAs biogenesis factors in ATL cells are still largely unknown. In this study, we assessed Dicer1 expression levels in ATL patients and investigated its transcriptional regulation in HTLV infected cell lines. We reported a significant correlation between reduced miRNA biogenesis and expression of HTLV-1 basic leucine zipper factor (HBZ). We showed that Dicer1 expression was downregulated in ATL patients vs. asymptomatic patients by qRT-PCR and western blot analysis. We also demonstrated that Dicer1 was regulated by AP-1 factors, through luciferase and Chip assays. Our data suggest that Dicer1 expression may be used as a promising prognostic marker and therapeutic target for ATL.

\section{Authors' details}

'CPBS, CNRS UMR 5236, Montpellier, France. ${ }^{2}$ CPBS, Université Montpellier 1 , Montpellier, France. ${ }^{3}$ Laboratoire de Virologie-Immunologie, Centre Hospitalier et Universitaire de Fort de France, Fort de France, Martinique, France.

Published: 7 January 2014

doi:10.1186/1742-4690-11-S1-055

Cite this article as: Gazon et al.: Deregulation of RNAi silencing pathway by Human T-cell leukemia virus type 1 bZIP factor (HBZ). Retrovirology 2014 11(Suppl 1):O55.

* Correspondence: jean-marie.peloponese@cpbs.cnrs.fr

${ }^{1}$ CPBS, CNRS UMR 5236, Montpellier, France

Full list of author information is available at the end of the article

Submit your next manuscript to BioMed Central and take full advantage of:

- Convenient online submission

- Thorough peer review

- No space constraints or color figure charges

- Immediate publication on acceptance

- Inclusion in PubMed, CAS, Scopus and Google Scholar

- Research which is freely available for redistribution
() Biomed Central 